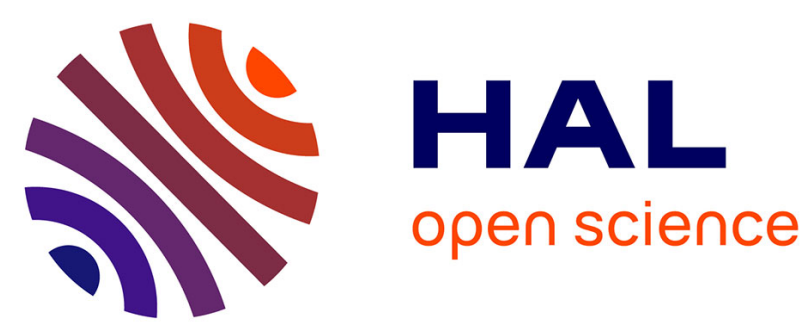

\title{
The Role of ICT-Based Information Systems in Knowledge Transfer Within Multinational Companies
}

Levente Szász, Maike Scherrer, Patricia Deflorin, Kozeta Sevrani, Betim Cico, Adrian Besimi, Kreshnik Vukatana, Béla Rácz

\section{- To cite this version:}

Levente Szász, Maike Scherrer, Patricia Deflorin, Kozeta Sevrani, Betim Cico, et al.. The Role of ICT-Based Information Systems in Knowledge Transfer Within Multinational Companies. IFIP International Conference on Advances in Production Management Systems (APMS), Sep 2017, Hamburg, Germany. pp.185-193, 10.1007/978-3-319-66923-6_22 . hal-01666168

\section{HAL Id: hal-01666168 https://hal.inria.fr/hal-01666168}

Submitted on 18 Dec 2017

HAL is a multi-disciplinary open access archive for the deposit and dissemination of scientific research documents, whether they are published or not. The documents may come from teaching and research institutions in France or abroad, or from public or private research centers.
L'archive ouverte pluridisciplinaire HAL, est destinée au dépôt et à la diffusion de documents scientifiques de niveau recherche, publiés ou non, émanant des établissements d'enseignement et de recherche français ou étrangers, des laboratoires publics ou privés.

\section{(c)(1)}

Distributed under a Creative Commons Attribution| 4.0 International License 


\title{
The role of ICT-based information systems in knowledge transfer within multinational companies
}

\author{
Levente Szász 1[0000-0001-8739-4097] , Maike Scherrer², Patricia Deflorin ${ }^{3}$, Kozeta Sev- \\ rani $^{4}$, Betim Cico ${ }^{5[0000-0001-9078-6147]}$, Adrian Besimi $^{5}$, Kreshnik Vukatana ${ }^{4[0000-0002-8779-}$ \\ ${ }^{0767]}$ and Béla Rácz ${ }^{1}$ \\ ${ }^{1}$ Babeș-Bolyai University, Cluj-Napoca, Romania \\ (levente.szasz@econ.ubbcluj.ro) \\ ${ }^{2}$ University of St. Gallen, St. Gallen, Switzerland \\ ${ }^{3}$ University of Applied Sciences HTW Chur, Chur, Switzerland \\ ${ }^{4}$ University of Tirana, Tirana, Albania \\ ${ }^{5}$ South East European University, Tetovo, Macedonia
}

\begin{abstract}
This paper focuses on the internal network of multinational companies (MNC) and aims to investigate the role of information systems (IS) based on modern information and communication technologies (ICT) in transferring knowledge between different plants of the MNC, a subject still debated in the literature. To shed more light on this relationship, we propose that in the context of the MNC, the plant's role in the knowledge network has to be taken into consideration.

The analysis is based on a case study approach with interviews conducted at thirteen manufacturing plants. Data analysis shows that plants can have two basic roles in the knowledge network: knowledge senders or knowledge receivers. Knowledge sending plants see IS less supportive in transferring knowledge, while most knowledge receivers rely heavily on some form of IS. Furthermore, IS proved unhelpful if the quality of data entered in the system was low, or when strategic support to allocate resources to use IS was missing.
\end{abstract}

Keywords: Information systems, Knowledge transfer, Manufacturing network, Multinational companies.

\section{Introduction}

Manufacturing companies have changed their way of producing products. Traditionally, a manufacturing company had one plant and served the world out of this plant. Today, many companies produce their product portfolios in a network consisting of several plants located in different countries. These plants represent the building blocks of the internal network of multinational companies (MNCs). To coordinate these plants, the flow of knowledge has been recognised as of key importance [5, 8, 27].

Beside the knowledge sending and receiving units, and the knowledge itself, benefits of a knowledge transfer process are also influenced by the connection between the sending and receiving unit $[16,24]$, including the mechanisms and channels used to transmit the knowledge [3]. Gupta and Govindarajan [9] show that these transmission 
mechanisms and channels positively influence the amount of knowledge shared, both at sending and receiving units. Almeida et al. [3] demonstrate that MNCs use a multitude of different transmission mechanisms to move knowledge across different intrafirm units. They also show that MNCs put a heavy emphasis on using information systems to facilitate knowledge transfer, including shared databases, common communication software, standardised design tools and file formats, company intranets, etc. Reviewing the literature on knowledge transfer within MNCs, Song [22] argues however that existing studies provide only limited information on how these transmission systems are used to transfer knowledge, and how their usage influences the benefits of the knowledge transfer. Thus, this paper aims to fill this gap by focusing on the role of a specific type of transmission systems, namely information systems (IS) based on modern information and communication technologies (ICT), in facilitating the knowledge transfer process within MNCs.

The role of IS in knowledge transfer is debated in the literature. While most of the studies find that IS supports knowledge transfer [e.g., 2, 11, 12, 23], some authors challenge this view $[10,20]$ arguing that IS can hardly contribute to organisational knowledge transfer $[13,19]$. This paper aims to contribute to this debate by proposing to take into consideration an additional factor, namely the role of the plant in the intraorganisational knowledge sharing processes within the MNC. Thus, we aim to answer the following research question (RQ):

How supportive are information systems for transferring knowledge between different plants of a multinational company?

\section{The role of plants within the knowledge flow in MNCs}

Knowledge transfer processes within an MNC are generally carried out between a knowledge-sending and a knowledge-receiving plant $[9,16,26]$. In this process, the driver for knowledge transfer is mainly the knowledge-receiving plant, as it faces problems that it cannot solve alone. After the knowledge transfer, the perception of the knowledge-receiving plant defines the knowledge transfer success [17].

Vereecke et al. [27] identified four distinct roles of a plant. They analysed the engagement of the individual plant related to the frequency of knowledge sending and receiving, innovation sending and receiving and whether the plant hosted visitors or how frequent own employees were sent to other plants. Based on this, Vereecke et al. [27] derived four plant roles, namely (1) the isolated plant, (2) the receiver, (3) the hosting network player, and (4) the active network player.

Szulanski [25] suggests to take into account the following elements when analysing knowledge transfer: the two actors of the knowledge transfer process, i.e. the knowledge-source and the knowledge-recipient, and the channel of knowledge transfer. The knowledge-source in our case is the knowledge sending plant within an MNC that needs to have the willingness and capacity to share knowledge with other units from within the network. On the other hand, knowledge receivers need to have the ability to absorb, i.e. identify, assimilate and exploit the knowledge provided by the sender. The main attention related to the channel has been on the relationship between knowledgesending and knowledge-receiving plants. Within the channel, transmission mechanisms 
play an important role, as these mechanisms can support the knowledge transfer process $[1,3]$. Literature discusses a wide range of mechanisms through which knowledge can be shared [7, 9, 22, 26], ICT/IS being among the most fundamental ones [3].

\section{The role of ICT-based IS in knowledge transfer}

Modern ICT-based IS play a crucial role in today's MNCs. According to O'Brien and Marakas [18, p. 4] "an information system (IS) can be any organized combination of people, hardware, software, communications networks, data resources, and policies and procedures that stores, retrieves, transforms, and disseminates information in an organization". IS in general can help the purpose to create, store, process, retrieve, transfer and apply data and information within organisations [2]. Here we focus mainly on the transfer component as we are interested in how ICT-based IS supports the knowledge transfer process between different plants of the same MNC.

Bigiardi et al. [4] argue that these systems based on information and communication technologies can be efficiently and effectively used to share intra-organisational knowledge. IS tools that make knowledge explicit, enable its transfer within multinational companies [14, 21]. Such tools include groupware, computer-supported cooperative work (electronic knowledge repositories, wikis), intranet, e-mail, portals and online communities [4, 6]. Iyengar et al. [11] show that the use of ICT systems significantly contributes to the effectiveness of the knowledge transfer at the receiver side as well. Jasimuddin et al. [12] bring several case examples where knowledge repository systems largely supported the knowledge transfer process between senders and receivers, but they also note that the correct introduction and classification of information in such systems is an important factor for receivers to find relevant knowledge. Sook-Ling et al. [23] offer further case study evidence for the usefulness of IT-based systems, such as knowledge repositories and e-mail systems, in sharing intra-organisational knowledge. Summarising the role of IS in knowledge transfer, Alavi and Leidner [2] argue that the positive contribution of these systems to the knowledge sharing process is based on three enabling factors: 1) IS has the potential to extend the reach of the internal network by connecting different isolated actors, 2) offers an increased variety of communication channels, and 3) it enables a faster access to knowledge sources.

Despite these enabling factors, several authors have criticised the general assumption that IS can significantly support the transfer of knowledge within an organisation. Alavi and Leidner [2] emphasise that if there is no overlap between the sender and receiver in their underlying knowledge base, then "the real impact of IT on knowledge exchange is questionable" (p. 112).

Roberts [20] also questions the role of IS in transferring knowledge, and argues that IS can not entirely replace the face-to-face interaction between sender and receiver, as "the transfer of know-how requires a process of show-how" (p. 439). Knowledge transfer requires socialisation, willingness to send and receive, and trust between the sender and receiver, which can be built via personal interactions. Hislop [10] raises similar critique, arguing that all knowledge has a non-codifiable element (that is not transferable via IS), and is deeply embedded in the activity, and social and cultural context of 
the knowledge sender. In light of these arguments, it is not surprising that Mageswari et al. [13], for example, have not found any significant relationship between IS utilisation and intra-organisational knowledge sharing. In their literature review, Panahi et al. [19] also conclude that the role of IS in knowledge transfer is currently uncertain (with supporting and opposing arguments both co-existing in the literature), and call for further research in this field.

\section{Methodology}

To gain an understanding of knowledge transfer, and especially of how IS supports the knowledge flow in manufacturing networks, we examined thirteen plants and analysed 24 examples of knowledge transfer projects. We used middle-range theory development [15], by linking theory and empirical work. We derived dimensions from theory and refined them through case study research. Eisenhardt and Graebner [14] recommend the case study approach for research interests such as ours, since the topic is not well documented and relatively unknown. The qualitative research approach provided us with deep insights into the selected case plants and allowed us to generate new insights. The plant level was selected as the unit of analysis to gain information in the needed level of detail.

An equal number of cases (three to four) was targeted in each of the four countries involved: Switzerland, Romania, Albania, and Macedonia. Field data were collected during 2016. The main method of data collection was a semi-structured interview, uniformly applied in each country. Researchers have participated in multiple interviews in different countries to enable a uniform understanding of data collection. After the data collection, the case data was first analysed within each respondent plant, followed by a cross-case analysis within and across countries.

\section{Data analysis}

To provide a detailed answer to our RQ, we first analysed the position of each individual plant within the knowledge network of MNCs. Based on interview data we tried to assess the extent to which each individual plant participates in (1) knowledge sending and (2) receiving, in (3) innovation sending and (4) receiving, and in (5) offering versus (6) receiving employee training (cf. [27]). Each of the six measures was rated with interviewees on a scale from None (0) to High (3), with Low (1) and Medium (2) as intermediary values, and a sum of these measures was computed at the end (Table 1).

Based on these ratings the overall position of each plant in the knowledge network has been assessed by adding up all sending/offering scores (i.e. knowledge sending, innovation sending, offering trainings) and subtracting the total score of receiving (i.e. knowledge receiving, innovation receiving, receiving trainings). Plants in the table are sorted based on their overall position. An overall score above zero indicates that the plant is more actively engaged in information and knowledge sending activities, and thus it can be categorised as a knowledge-sender (S2, S3, S1), while a negative score 
indicates that the plant should be viewed as a primarily knowledge-receiving unit (A3, M3, R1, R3, A1, M1, A2, A4, R2).

Table 1. The position of interviewed plants in the knowledge network

\begin{tabular}{|c|c|c|c|}
\hline Plant code & Sum of position & Plant code & Sum of position \\
\hline S2 & $2.5+3+3-1-1-1=\mathbf{5 . 5}$ & R1 & $2+1+2-3-3-3=-4$ \\
\hline S3 & $2+3+3-2-1-1=\mathbf{4}$ & R3 & $2+1+1-3-3-3=-5$ \\
\hline S1 & $2+1+3-1-1-1=\mathbf{3}$ & $\mathrm{A} 1$ & $1+1+1-3-3-2=\mathbf{- 5}$ \\
\hline M2 & $3+3+1-3-3-2=-1$ & M1 & $0+1+1-3-2-2=\mathbf{- 5}$ \\
\hline A3 & $2+2+1-2-2-2=-1$ & A2 & $0+0+1-3-0-3=-\mathbf{5}$ \\
\hline M3 & $2+1+1-2-3-3=-4$ & A4 & $1+1+0-3-3-2=-6$ \\
\hline \multicolumn{2}{|c|}{ (continued in next column) } & $\mathrm{R} 2$ & $1+0+1-3-3-3=-7$ \\
\hline
\end{tabular}

Thus, to investigate the role of IS in knowledge transfer, we divide our analysis into two parts, the first related to net knowledge sending plants (Table 2), and the second to knowledge receiving plants (Table 3). Interviewees were asked to identify one or two recent knowledge transfer projects and to rate and discuss the role of modern ICT-based IS in supporting knowledge exchange.

Table 2. The role of IS in knowledge transfer at knowledge sending plants

\begin{tabular}{|c|l|l|c|}
\hline $\begin{array}{c}\text { Plant } \\
\text { code }\end{array}$ & $\begin{array}{c}\text { Knowledge } \\
\text { transfer project }\end{array}$ & \multicolumn{1}{|c|}{ Role of IS } & $\begin{array}{c}\text { IS sup- } \\
\text { port }\end{array}$ \\
\hline \multirow{2}{*}{ S1 } & $\begin{array}{l}\text { Product transfer } \\
\text { to US plant }\end{array}$ & $\begin{array}{l}\text { Helpful for storing information, but face-to-face } \\
\text { meetings and employee exchange were more used. }\end{array}$ & Partial \\
\cline { 2 - 4 } & $\begin{array}{l}\text { Implementing a } \\
\text { production line in } \\
\text { a French plant }\end{array}$ & $\begin{array}{l}\text { All necessary knowledge was provided in a com- } \\
\text { mon database, but the knowledge intake was re- } \\
\text { fused by French plant }\end{array}$ & No \\
\hline \multirow{2}{*}{ S2 } & $\begin{array}{l}\text { Skilling up Polish } \\
\text { plant }\end{array}$ & $\begin{array}{l}\text { The common online platform used was helpful, be- } \\
\text { cause the high quality of the data introduced. }\end{array}$ & Yes \\
\cline { 2 - 4 } & $\begin{array}{l}\text { Product transfer } \\
\text { to Polish plant }\end{array}$ & $\begin{array}{l}\text { Although an IS was in place for knowledge trans- } \\
\text { fer, it could not be used due to bad data quality. }\end{array}$ & No \\
\hline \multirow{2}{*}{ S3 } & $\begin{array}{l}\text { Process introduc- } \\
\text { tion in a HU plant }\end{array}$ & $\begin{array}{l}\text { The transfer of crucial knowledge could only be } \\
\text { carried out through personal interaction. }\end{array}$ & No \\
\hline
\end{tabular}

Interview data indicated that although all knowledge sending plants had multiple, cutting edge IS in place, they were only rarely used. Bad quality of data introduced in the system was one of the reasons mentioned. For some of the projects, IS was simply not used because the complexity of the project required a more intensive face-to-face interaction. The only response supporting the contribution of IS to the knowledge exchange was offered for a project, which was of strategic importance for the company, and thus enough resources were deployed for the proper functioning of the system.

On the other hand, knowledge receiving units generally use IS to support the transfer of knowledge. Compared to knowledge sending plants, in general, they perceive that IS offer much more support for knowledge transfer. Several respondents argued that IS actually represents the first and foremost channel for acquiring knowledge, which is afterwards complemented with face-to-face knowledge sharing. 
Both cases where IS was not reported as being supportive for knowledge transfer from the knowledge-receiving manager's perception had bad data issues: for one project (R2, new component manufacturing) the data was mostly missing due to the innovative nature of the product and the time pressure around manufacturing its components, while for the other project (M3, implementation of safety standards) the system had stored high quantities of useful information (hundreds of safety standards), but it was organised in a manner that "required a lot of time to process".

Table 3. The role of IS in knowledge transfer at knowledge receiving plants

\begin{tabular}{|c|c|c|c|}
\hline $\begin{array}{l}\text { Plant } \\
\text { code }\end{array}$ & $\begin{array}{l}\text { Knowledge trans- } \\
\text { fer project }\end{array}$ & Role of IS & $\begin{array}{l}\text { IS sup- } \\
\text { port }\end{array}$ \\
\hline \multirow{2}{*}{ R1 } & $\begin{array}{l}\text { Implementing lean } \\
\text { techniques }\end{array}$ & $\begin{array}{l}\text { Online platforms were frequently used to ask ex- } \\
\text { perts for best practices }\end{array}$ & Yes \\
\hline & $\begin{array}{l}\text { ERP implementa- } \\
\text { tion }\end{array}$ & $\begin{array}{l}\text { Face-to-face trainings had to be used, only } \\
\text { some information was acquired through IS }\end{array}$ & Partly \\
\hline \multirow{2}{*}{$\mathrm{R} 2$} & $\begin{array}{l}\text { New component } \\
\text { manufacturing }\end{array}$ & $\begin{array}{l}\text { New product with fast growing sales: know- } \\
\text { ledge exchange was mainly human-to-human }\end{array}$ & No \\
\hline & $\begin{array}{l}\text { Implementing an In- } \\
\text { dustry } 4.0 \text { project }\end{array}$ & $\begin{array}{l}\text { The project involved a lot of standardised infor- } \\
\text { mation which were provided through IS. }\end{array}$ & Yes \\
\hline \multirow{2}{*}{$\mathrm{R} 3$} & $\begin{array}{l}\text { Implementing a } \\
\text { TPM system }\end{array}$ & $\begin{array}{l}\text { IS was used to transfer project management in- } \\
\text { formation from other units with experience }\end{array}$ & Yes \\
\hline & $\begin{array}{l}\text { Implementing work } \\
\text { safety standards }\end{array}$ & $\begin{array}{l}\text { IS was only partly used to receive the new } \\
\text { standards and then monitor KPIs }\end{array}$ & Partly \\
\hline \multirow{2}{*}{ A1 } & Inventory reduction & $\begin{array}{l}\text { Video conference used to share knowledge on } \\
\text { recycling, leading to inventory reduction }\end{array}$ & Yes \\
\hline & $\begin{array}{l}\text { New product manu- } \\
\text { facturing }\end{array}$ & $\begin{array}{l}\text { Steps of new product implementation, that was } \\
\text { documented and shared through IS }\end{array}$ & Yes \\
\hline \multirow{2}{*}{ A 2} & $\begin{array}{l}\text { Changing product } \\
\text { „,recipe”, }\end{array}$ & $\begin{array}{l}\text { For quality } H Q \text { decided to change the recipe of } \\
\text { a product, sharing a how-to manual through IS. }\end{array}$ & Yes \\
\hline & $\begin{array}{l}\text { Standardisation of } \\
\text { controlling }\end{array}$ & $\begin{array}{l}\text { IS tools helped the HQ to transfer a standard- } \\
\text { ised communication guideline with authorities }\end{array}$ & Yes \\
\hline \multirow{2}{*}{ A3 } & $\begin{array}{l}\text { Improving produc- } \\
\text { tion standards }\end{array}$ & $\begin{array}{l}\text { Sharing documentation and manuals with other } \\
\text { plants through IS }\end{array}$ & Yes \\
\hline & $\begin{array}{l}\text { Improving safety } \\
\text { standards }\end{array}$ & $\begin{array}{l}\text { Incremental improvements of safety standards } \\
\text { through IS in a periodical manner }\end{array}$ & Yes \\
\hline \multirow{2}{*}{ A4 } & $\begin{array}{l}\text { New product intro- } \\
\text { duction }\end{array}$ & $\begin{array}{l}\text { IS helped to transfer new product knowledge } \\
\text { from } H Q \text {, introduced in the local market }\end{array}$ & Yes \\
\hline & $\begin{array}{l}\text { Product transfer } \\
\text { from Austrian plant }\end{array}$ & $\begin{array}{l}\text { Lack of a common system made hard to exploit } \\
\text { the whole facilities and efficiency of IS }\end{array}$ & Partly \\
\hline M1 & $\begin{array}{l}\text { New product manu- } \\
\text { facturing }\end{array}$ & $\begin{array}{l}\text { A centralised IS was used to transfer knowledge } \\
\text { that was fully standardised. }\end{array}$ & Yes \\
\hline \multirow{2}{*}{ M2 } & $\begin{array}{l}\text { New raw material } \\
\text { introduction }\end{array}$ & $\begin{array}{l}\text { Measures from the intranet portal was used to- } \\
\text { gether with experts' support }\end{array}$ & Yes \\
\hline & $\begin{array}{l}\text { New product manu- } \\
\text { facturing }\end{array}$ & $\begin{array}{l}\text { Intranet portal was combined with regular } \\
\text { meetings on project development. }\end{array}$ & Partly \\
\hline \multirow{2}{*}{ M3 } & $\begin{array}{l}\text { Production process } \\
\text { improvement }\end{array}$ & $\begin{array}{l}\text { Quality and process related knowledge acquired } \\
\text { from central database }\end{array}$ & Yes \\
\hline & $\begin{array}{l}\text { Implementation of } \\
\text { safety standards }\end{array}$ & $\begin{array}{l}\text { Too much time needed to process the over- } \\
\text { loaded knowledge content in the system. }\end{array}$ & No \\
\hline
\end{tabular}




\section{Discussion and Conclusion}

This paper looked at the role of ICT-based IS in the intra-organisational knowledge transfer within the internal network of manufacturing MNCs. Our results show that, indeed, in most of the cases IS plays a central role in transferring knowledge between different units, which is in line with the mainstream assumptions in IS literature [3, 11]. However, in line with the case findings of Jasimuddin et al. [12], we also argue that the data quality and strategic commitment towards using IS for transferring knowledge is an important precondition. Besides offering further support for previous findings, our results bring important new insights as well. We argue that the role of the plant in the internal knowledge network (i.e. knowledge sender or receiver) has to be also taken into consideration. Our findings show that this distinction can offer at least a partial explanation for the debated role of IS in knowledge transfer [e.g., 19, 20].

Knowledge sending plants in our sample see IS less beneficial for transferring knowledge. We argue that knowledge senders have to transfer complex knowledge "packages", which contains both codified and tacit knowledge elements. This explanation is in line with the practice-based approach of knowledge transfer put forward by Hislop [10]. Thus, for a successful knowledge sending project, transmission mechanisms that are able to transfer non-codifiable knowledge are absolutely essential, i.e. different forms of personal interactions are more important for sending knowledge.

Knowledge receiving plants, on the other hand, report that IS is helpful in most of the knowledge transfer projects. We argue that in a receiver position, the plant is motivated to find the relevant knowledge for a certain situation or problem. Regardless of the type of the knowledge searched for, the most convenient way to acquire it, is to transfer it through an IS [cf. 11]. If this transfer is not enough, IS-based knowledge transfer was complemented in several cases by face-to-face interactions or trainings. Thus, in contrast to knowledge senders, receiver plants see IS as a primary enabler of knowledge transfer that may or may not be complemented with personal interaction.

\section{References}

1. Adenfelt M, Lagerström K (2008) The Development and Sharing of Knowledge by Centres of Excellence and Transnational Teams: A Conceptual Framework. Management International Review (MIR) 48:319-338

2. Alavi M, Leidner DE (2001) Review: Knowledge management and knowledge management systems: Conceptual foundations and research issues. MIS quarterly 25:107-136

3. Almeida P, Song J, Grant RM (2002) Are firms superior to alliances and markets? An empirical test of cross-border knowledge building. Organization Science 13:147-161

4. Bigliardi B, Ivo Dormio A, Galati F (2010) ICTs and knowledge management: an Italian case study of a construction company. Measuring Business Excellence 14:16-29

5. Chew BW, Bresnahan TF, Clark. KB (1990) Measurement, coordination and learning in a multiplant network. In: Kaplan RS (ed) Measures for Manufacturing Excellence. Harvard Business School Press, Boston, MA, p 129-162

6. Di Gangi PM, Wasko MM, Tang X (2012) Would You Share?: Examining Knowledge Type and Communication Channel for Knowledge Sharing Within and Across the Organizational Boundary. International Journal of Knowledge Management (IJKM) 8:1-21 
7. Erden Z, Klang D, Sydler R et al. (2014) Knowledge-flows and firm performance. Journal of Business Research 67:2777-2785

8. Ferdows K (2006) Transfer of Changing Production Know-How. Production \& Operations Management 15:1-9

9. Gupta AK, Govindarajan V (2000) Knowledge flows within multinational corporations. Strategic Management Journal 21:473-496

10. Hislop D (2002) Mission impossible? Communicating and sharing knowledge via information technology. Journal of Information Technology 17:165-177

11. Iyengar K, Sweeney JR, Montealegre R (2015) Information technology use as a learning mechanism: The impact of IT use on knowledge transfer effectiveness, absorptive capacity, and franchisee performance. Mis Quarterly 39:615-641

12. Jasimuddin SM, Connell N, Klein JH (2012) Knowledge transfer frameworks: an extension incorporating knowledge repositories and knowledge administration. Information Systems Journal 22:195-209

13. Mageswari SU, Sivasubramanian C, Dath TS (2015) Knowledge management enablers, processes and innovation in small manufacturing firms: A structural equation modeling approach. IUP Journal of Knowledge Management 13:33-58

14. Malhotra A, Gosain S, Sawy OaE (2005) Absorptive capacity configurations in supply chains: gearing for partner-enabled market knowledge creation. MIS quarterly:145-187

15. Merton RK (1968) Social Theory and Social Structure. The Free Press, New York

16. Minbaeva DB (2007) Knowledge transfer in multinational corporations. Management International Review 47:567-593

17. Monteiro LF, Arvidsson N, Birkinshaw J (2008) Knowledge Flows within Multinational Corporations: Explaining Subsidiary Isolation and Its Performance Implications. Organization Science 19:90-107

18. O'brien JA, Marakas G (2012) Introduction to information systems. McGraw-Hill, Inc., New York

19. Panahi S, Watson J, Partridge H (2013) Towards tacit knowledge sharing over social web tools. Journal of Knowledge Management 17:379-397

20. Roberts J (2000) From know-how to show-how? Questioning the role of information and communication technologies in knowledge transfer. Technology Analysis \& Strategic Management 12:429-443

21. Schreiber D, Junior V, Chaves D et al. (2011) Knowledge transfer in product development: an analysis of Brazilian subsidiaries of multinational corporations. BAR-Brazilian Administration Review 8:288-304

22. Song J (2014) Subsidiary absorptive capacity and knoweldge transfer within multinational corporatinos. Journal of International Business Studies 45:73-84

23. Sook-Ling L, Ismail MA, Yee-Yen Y (2015) Information infrastructure capability and organisational competitive advantage: framework. International Journal of Operations \& Production Management 35:1032-1055

24. Szulanski G (1996) Exploring internal stickiness: Impediments to the transfer of best practice within the firm. Strategic Management Journal 17:27-43

25. Szulanski G (2000) The Process of Knowledge Transfer: A Diachronic Analysis of Stickiness. Organizational Behavior and Human Decision Processes 82:9-27

26. Tseng C-H (2015) Determinants of MNC's Knowledge Inflows to Subsidiaries: A Perspective on Internalization Advantages. Management International Review 55:119-150

27. Vereecke A, Van Dierdonck P, De Meyer A (2006) A Typology of Plants in Global Manufacturing Networks. Management Science 52:1737-1750

Acknowledgement: We would like to thank the Swiss National Science Foundation (SCOPES Joint Research Project IZ73Z0_152505) for the financial support provided for the research project discussed in this paper. 